\title{
References
}

1. Tsyfrovi kompetentsii yak umova formuvannia yakosti liudskoho kapitalu : analit. zap. / [V. S. Kuibida, O. M. Petroie, L. I. Fedulova, H. O. Androshchuk]. - Kyiv : NADU, 2019. - 28 s. (data zvernennia: 05.11.2019) [in Ukrainian].

2. Problemy ta perspektyvy harmonizatsii tsyfrovoho rynku Ukrainy z rynkamy YeS ta krain SkhP : analit. Zvit / [V. Nochvai, M. Koriavets, I. Kulchytskyi, L. Oleksiuk, O. Prykhodko, K. Horokhovskyi, V. Hryha]: veb-sait. URL: https://cid.center/wp-content/uploads/2019/02/analitychnyi-zvit-SkhP.pdf (data zvernennia: 05.11.2019) [in Ukrainian].

3. Definition and Selection of Competencies. Theoretical and Conceptual Foundations (DESECO). Strategy Paper on Key Competencies. An Overarching Frame of Reference for an Assessment and Research Program - OECD (Draft). [Electronic resource]. - Access mode: http://www.deseco. admin.ch. (accessed 30 October 2019) [in English].

4. The Digital Competence Framework for Citizens. [Electronic resource]. - Access mode:http://publications.jrc.ec.europa.eu/repository/bitstream/JRC106281 (accessed 28 October 2019) [in English].

5. A Digital Agenda for Europe. [Electronic resource]. - Access mode: https://eur-lex.europa.eu/legalcontent/EN/ALL/?uri=CELEX:52010DC0245R(01) (accessed 28 October 2019) [in English].

6. The Entrepreneurship 2020 Action Plan. [Elektronnyi resurs]. - Rezhym dostupu: https://ec.europa.eu/growth/smes/promoting-entrepreneurship/action-plan_en (accessed 30 October 2019) [in English].

7. "Europe 2020" Strategy [Electronic resource]. - Access mode: http://ec.europa.eu/europe2020/index_en.htm (accessed 30 October 2019) [in English].

8. The Key Competences for Lifelong Learning - A European Framework. [Electronic resource]. - Access mode: https://www.erasmusplus.org.uk/file/272/download (accessed 28 October 2019) [in English].

9. Strategic framework "Education and Training 2020" (ET2020) - [Electronic resource] - Access mode: http://europa.eu/legislation_summaries/education_training_youth/general_framework/ef0016en.htm (accessed 30 October 2019) [in English].

Стаття надійшла до редакції 16.11.2019 р.

УДК 331.103 .3

Устіловська Анастасія, аспірант, викладач,

Харківський національний університет будівництва та архітектури, кафедра економіки,

м. Харків, ORCID ID 0000-0002-9297-7614 e-mail: ustilovskaya.an@ukr.net

https://doi.org/10.29038/2411-4014-2019-04-100-108

\section{ФОРМУВАННЯ ІННОВАЦЙНИХ МЕТОДІВ УПРАВЛІННЯ ПЕРСОНАЛОМ У РОЗРІЗІ ПРАКСЕОЛОГІЧНОГО ПІДХОДУ}

Як відомо, один з основних ресурсів та джерелом отримання вигод для підприємства $є$ його персонал, та належне його функціонування, в цілому, не можливе без впливу на нього з боку керівництва, що й стало запорукою створення системи управління персоналом. Комплексне поняття «управління персоналом» вказує на те, що процес впливу на працівників можливе лише з використанням спеціальних засобів і методів. В сучасних умовах господарювання досить актуальними стають радикально нові, інноваційні методи управління, до яких також відносять праксеологічний підхід. В традиційні методи управління персоналом 3 огляду на праксеологічний підхід доцільне введення ще однієї складової «методи формування ефективної поведінки персоналу». 
Ключові слова: праксеологія, управління персоналом, методи управління персоналом, інновації, інноваційні методи, персонал-технології.

Устиловская Анастасия, аспирант, преподаватель, Харьковский национальный университет строительства и архитектуры, кафедра экономики, г. Харьков

\section{ФОРМИРОВАНИЕ ИННОВАЦИОННЫХ МЕТОДОВ УПРАВЛЕНИЯ ПЕРСОНАЛОМ В РОЗРЕЗЕ ПРАКСЕОЛОГИЧЕСКОГО ПОДХОДА}

Как известно, один из основных ресурсов и источников получения выгод для предприятия является его персонал, и надлежащее его функционирования, в целом, невозможно без воздействия на него со стороны руководства, что и стало залогом создания системы управления персоналом. Комплексное понятие «управление персоналом» указывает на то, что процесс воздействия на работников возможно только с использованием специальных средств и методов. В современных условиях хозяйствования весьма актуальными становятся радикально новые, инновационные методы управления, к которым также относят праксеологический подход. В традиционные методы управления персоналом с учетом праксеологического подхода целесообразно введение еще одной составляющей «методы формирования эффективного поведения персонала».

Ключевые слова: праксеология, управление персоналом, методы управления персоналом, инновации, инновационные методы, персонал-технологии.

Ustilovska Anastasiia, postgraduate, lecturer

Kharkiv National University of Civil Engineering and Architecture, Department of Economy, Kharkiv

\section{FORMATION OF INNOVATIVE HUMAN RESOURCES MANAGEMENT METHODS AS A PROXEOLOGICAL APPROACH}

As you know, one of the main resources and sources of benefits for the enterprise is its personnel, and its proper functioning, in general, is impossible without the influence of management on it, and has become the key to creating a personnel management system. The comprehensive concept of «personnel management» indicates that the process of influencing workers is possible only using special tools and methods. In modern business conditions, radically new, innovative management methods, which also include the praxeological approach, are becoming very relevant. In the traditional methods of personnel management, taking into account the praxeological approach, it is advisable to introduce one more component, «methods for the formation of effective personnel behavior». The purpose of the article is to reveal the essence of a comprehensive definition of personnel management. Formation of innovative methods of personnel management and introduction of their groups into the classification. Defining the classification of technology personnel from the aspect of innovative methods of personnel management. Defining a praxeological approach in personnel management and constructing a schematic representation of the praxeological outline of the concepts of «personnel», «management», «innovation», «method» and «innovative methods of personnel management». Introduced by the author in the classification a group of methods that will allow to carry out a continuous process (planning, hiring, evaluation, development and motivation) influence of the company management on the interests, behavior and activities of employees (who have industrial relations with the employer, skilled or unskilled, may have experience or not to have it at the time of the employment contract), using newly created and / or improved methods of influence in order to achieve the tactical and strategic goals of the enterprise. The complex concept of personnel management is formed. The scheme of praxeological outline of the concepts of «personnel», «management», «innovation», «method» and «innovative methods of personnel management».

Key words: praxeology, personnel management, personnel management methods, innovations, innovative methods, personnel technologies. 
Постановка проблеми. Традиційні методи управління персоналом є узагальненими та не відповідають вимогам сьогодення, що вказує на розробку інноваційних методів управління персоналом які формуються через праксеологічний підхід.

Аналіз останніх публікацій. Дослідженню управління персоналом присвячено наукові праці таких вчених, як Калініченко Л.Л., Смачило В.В., Чупир О.М., Міхова Л. І., Стояненко І.В., Дерунця Я.В., Єсінової Н.I., Зайченко О.І., Кузнецової В.І. Бульш детальне дослідження саме методів управління персоналом відмічається у наукових працях таких науковців, як Касич А.О., Бурби О.А., Лизунової О.М., Іщенко Я.Г., Кондрашової Г.В.

Постановка завдання. Мета статті полягає у розкритті сутності комплексного визначення управління персоналом. Формуванні інноваційних методів управління персоналом та введення їх груп в класифікацію. Визначення класифікації персонал-технологій з аспекту інноваційних методів управління персоналом. Визначення праксеологічного підходу в управлінні персоналом та побудова схематичного зображення праксеологічного контуру понять «персонал», «управління», «інновації», «метод» та «інноваційні методи управління персоналом».

Виклад основного матеріалу. В рамках дослідження управління персоналом предметами дослідження стають «парадигма управління» та розгляд ролі людини, як виробника. Відповідно, доцільно провести дослідження діяльність людини, іiі можливостей саме в аспекті ефективності. Характеристика реальних людських можливостей, об'єктивних i суб'єктивних дій людини, формування іiі ідеалів і цінностей, законів життєдіяльності і життєзабезпечення як індивідуума, так і суспільства можливі за допомогою використання праксеологічного підходу. За його допомогою висвітлюється проблематика праксеологічної діяльності людей, спрямованої на перетворення природи і суспільства, відтворення продуктивних сил й суспільних відносин. Даний підхід зорієнтований на дослідження людських можливостей через призму практичної успішності. Основне завдання праксеологічного підходу - вивчення, пошук і впровадження всього необхідного для ефективної діяльності людини. Праксеологія дозволяє розширити понятійний та категорійний апарат та забезпечити ментальну сферу практичної діяльності поняттями інструментального характеру: засобами, методами, технологіями.

Праксеологія (від грец. praxis - дія) - це соціально-філософська концепція діяльності. Праксеологію вважають міждисциплінарною галуззю знання, що зорієнтована на розробку методологічних основ ефективної раціональної діяльності у суспільстві.

Праксеологія - це наука про організацію та управління будь-якою людською діяльністю з метою iї оптимізації, з метою покращення іiї ефективності. Мета праксеології - знайти загальні закони будьякої людської діяльності, щоб на їхній основі сформулювати загальні принципи людської діяльності в аспекті їі ефективності [1].

Сфера праксеологічних досліджень пропонує три рівні аналізу діяльності людині:

1) Типологія діяльності та формуванні відповідної системи категорій.

2) Розробка ефективних нормативних систем діяльності у контексті конкретних соціокультурних та виробничих умов.

3) Критичне осмислення людської діяльності з погляду іiі методів та перспектив розвитку в соціумі.

Першим етапом праксеологічного підходу є ретельне вивчення категорійного та понятійного апаратів визначеної проблематики.

На думку автора, поняття персоналу, що обмежується постійними кваліфікованими досвідченими працівниками не враховує сучасні особливості прийому персоналу, такі як випробувальний термін, стажування, створення робочого місця спеціально для отримання практичного досвіду, підвищення кваліфікації або перекваліфікації тощо. Автор схиляється до ширшого поняття персонал. Персонал (на думку авторів) - це працівники, які мають виробничі відносини з роботодавцем, кваліфіковані або некваліфіковані, можуть мати досвід чи не мати його на момент заключення трудового договору. Персонал включає в себе всіх працівників організації, сезонних працівників, тимчасових працівників, працюючих за сумісництвом та інших, а також кадри.

Функціонування персоналу та підприємства в цілому неможливе без впливу на працівників 3 боку керівництва, тому з'являється потреба в створенні системи управління персоналом. Управління 
- процес цілеспрямованого впливу на систему (механічну, технологічну, біологічну, соціальну), в результаті якого досягається їі впорядкованість, розвиток у відповідності з поставленими цілями [2].

Першочергове розуміння досягнення «цілей та завдань», «вигод», «ефективної діяльності» характеризувалися отриманням економічних ресурсів та економією витрат. Сучасне розуміння «вигод» зміщене у бік підвищення впорядкованості та результативності спільної діяльності людей за рахунок корегування поведінкових аспектів, оптимізації та синхронізації міжособових та внутрішньо колективних відносин людей.

Таким чином, поступово здійснюється перехід 3 «об'єктивних» цільових критеріїв, до «суб'єктивних», що базуються на результатах організаційної поведінки, та створенні моделей ситуаційного управління.

Зазначений перехід дозволяє підприємству не лише отримувати запланований прибуток від діяльності, а й ставити інші цілі управління: підвищення якості, конкурентоздатності, економічної стійкості, інноваційної, екологічності, соціальної відповідальності тощо. Система управління персоналом, що побудована на базі праксеологічного підходу, дозволяє сучасним підприємствам адаптуватись до постійних, а іноді і моментальних, трансформацій у зовнішньому середовищі, зайняти лідуючи позиції в своїй галузі.

На основі власних досліджень автором сформоване власне визначення стосовно управління персоналом підприємства (табл. 1).

\section{Формування комплексного поняття «управління персоналом»}

Таблиия 1

\begin{tabular}{|c|c|c|}
\hline Пон & Поняття «управління» & $\begin{array}{c}\text { Комплексне визначення } \\
\text { поняття «управління } \\
\text { персоналу» }\end{array}$ \\
\hline \multirow{4}{*}{$\begin{array}{l}\text { Персонал (на думку } \\
\text { автора) - це } \\
\text { працівники, які мають } \\
\text { виробничі відносини з } \\
\text { роботодавцем, } \\
\text { кваліфіковані або } \\
\text { некваліфіковані, } \\
\text { можуть мати досвід чи } \\
\text { не мати його на } \\
\text { момент заключення } \\
\text { трудового договору. } \\
\text { Персонал включає в } \\
\text { себе всіх працівників } \\
\text { організації, сезонних } \\
\text { працівників, } \\
\text { тимчасових } \\
\text { працівників, } \\
\text { працюючих за } \\
\text { сумісництвом та } \\
\text { інших, а також кадри. }\end{array}$} & & \multirow{4}{*}{$\begin{array}{l}\text { Управління персоналом - } \\
\text { безперервний процес } \\
\text { (планування, наймання, } \\
\text { оцінювання, розвиток та } \\
\text { мотивація) впливу керівництва } \\
\text { підприємства на інтереси, } \\
\text { поведінку й діяльність } \\
\text { працівників (які мають } \\
\text { виробничі відносини з } \\
\text { роботодавцем, кваліфіковані } \\
\text { або некваліфіковані, можуть } \\
\text { мати досвід чи не мати його на } \\
\text { момент заключення трудового } \\
\text { договору), з використанням } \\
\text { організаційно-економічних, } \\
\text { адміністративно- } \\
\text { управлінських, правових і } \\
\text { особистісних факторів, } \\
\text { засобів, методів впливу з } \\
\text { метою досягнення тактичних } \\
\text { та стратегічних цілей } \\
\text { підприємства. }\end{array}$} \\
\hline & $\begin{array}{l}\text { Прикладна наука, що займається } \\
\text { дослідженням організаційно- } \\
\text { економічних, адміністративно- } \\
\text { управлінських, правових і особистісних } \\
\text { факторів та розробкою і впровадження } \\
\text { способів, методів впливу на персонал } \\
\text { підприємств. }\end{array}$ & \\
\hline & $\begin{array}{l}\text { Цілеспрямована діء } \\
\text { підприємства, керіг } \\
\text { підрозділів системи } \\
\text { персоналом на інте } \\
\text { діяльність працівни } \\
\text { максимального вик } \\
\text { потенціалу при вик } \\
\text { функцій[3]. }\end{array}$ & \\
\hline & $\begin{array}{l}\text { Процес (планування, наймання, } \\
\text { оцінювання, розвиток та мотивація)впливу } \\
\text { на персонал, спрямований на ефективне } \\
\text { його використання та досягнення цілей } \\
\text { підприємства та працівників[4]. }\end{array}$ & \\
\hline
\end{tabular}

Виходячи 3 визначення поняття «управління персоналом» процес впливу на працівників можливий лише з використанням спеціальних засобів і методів.

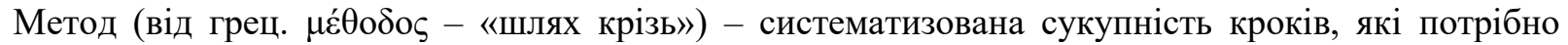
здійснити, щоб виконати певну задачу чи досягти певної мети; поняття тотожне алгоритму дій і технологічному процесу. 
Метод у найзагальнішому значенні - це певний спосіб дослідження якоїсь проблеми чи завдання, тобто метод являє собою систему правил, принципів і прийомів підходу до вивчення явищі закономірностей розвитку природи, суспільства і мислення або практичної перетворюючої діяльності людини [7].

Методи - спосіб досягнення якої-небудь мети, вирішення конкретного завдання або ж сукупність прийомів освоєння дійсності [2]; спосіб досягнення мети, цілі, програми, плану завдяки впорядкованій певним чином діяльності [10].

На думку автора методи управління персоналом - це способи впливу керівництва підприємства на інтереси, поведінку й діяльність працівників (які мають виробничі відносини з роботодавцем, кваліфіковані або некваліфіковані, можуть мати досвід чи не мати його на момент заключення трудового договору).

В наукових працях вітчизняних та закордонних вчених пропонується ряд методів ефективного управління персоналом. До класичних методів відносять: адміністративні, економічні та соціальнопсихологічні.

3 розвитком відносин у суспільстві розвиваються й виробничі відносини між керівництвом підприємств та їх персоналом. Саме тому методи управління персоналом постійно еволюціонують. Керівництво підприємства знаходиться в постійному пошуку нових методів та інструментів управління. Останнім часом, досить актуальними стають радикально нові, інноваційні методи управління, до них відноситься і праксеологічний підхід (орієнтація управління на зміну поведінки працівника). Характер управління стає більш «людяним», фокусуючись на людях як головній конкурентній перевазі підприємства,створюються умови, що дозволять персоналу застосовувати у роботі унікальні людські якості - емоційний інтелект, креативність, інноваційність тощо.

Термін «інновація» вперше ввів американський учений Йозеф Алоіз Шумпетер у першому десятилітті XX ст. Первинне поняття «інновація» трактувалося як зміна 3 метою впровадження й використання нових видів споживчих товарів, нових виробничих, транспортних засобів, ринків $\mathrm{i}$ форм організації в промисловості.

Згідно Закону України «Про інноваційну діяльність» інновація є новостворені (застосовані) $\mathrm{i}$ (або) вдосконалені конкурентоздатні технології, продукція або послуги, а також організаційнотехнічні рішення виробничого, адміністративного, комерційного або іншого характеру, що істотно поліпшують структуру та якість виробництва і (або) соціальної сфери [8].

Інновація - це введення в експлуатацію будь-якого нового або значно поліпшеного продукту (товару або послуги) або процесу, нового методу маркетингу або нового організаційного методу у діловій практиці, організації робочих місць або зовнішніх зв'язках [9].

Інновації - новостворені вдосконалені конкурентоздатні технології, продукція або послуги, а також організаційно-технічні рішення виробничого, адміністративного, комерційного або іншого характеру, що істотно поліпшують структуру та якість виробництва і (або) соціальної сфери [10].

Дослідивши останні трактування поняття «інновація», як економічної категорії, можна сказати, що кожне 3 них містить складову сфери управління. Інакше кажучи, поняття «інновація» не обмежується лише матеріальною сферою, а новітні методи управління - $є$ інноваціями, що змінюють соціально-економічні відносини. Саме тому, на думку автора доцільно дати чітке визначення поняттю «інноваційні методи управління персоналом» (рис. 1).

При застосуванні праксеологічного підходу виявляють норми та правила поведінки людини. Виявлені норми та правила досліджують на предмет доцільності використання їх в сучасному середовищі з точки зору ефективності. Виявивши застарілі (неефективні) норми поведінки людини в тій чи іншій сфері науковці пропонують замінювати їх на нові, сучасні, інноваційні.

Застосування праксеологічного підходу при дослідженні процесу управління персоналом дозволило порівняти класичні та інноваційні погляди науковців на зазначені категорії. Виявити вже неефективні з них та замінити на сучасні. 
РОЗДІЛ ІІІ. Економіка та управління підприсмствами. 4, 2019

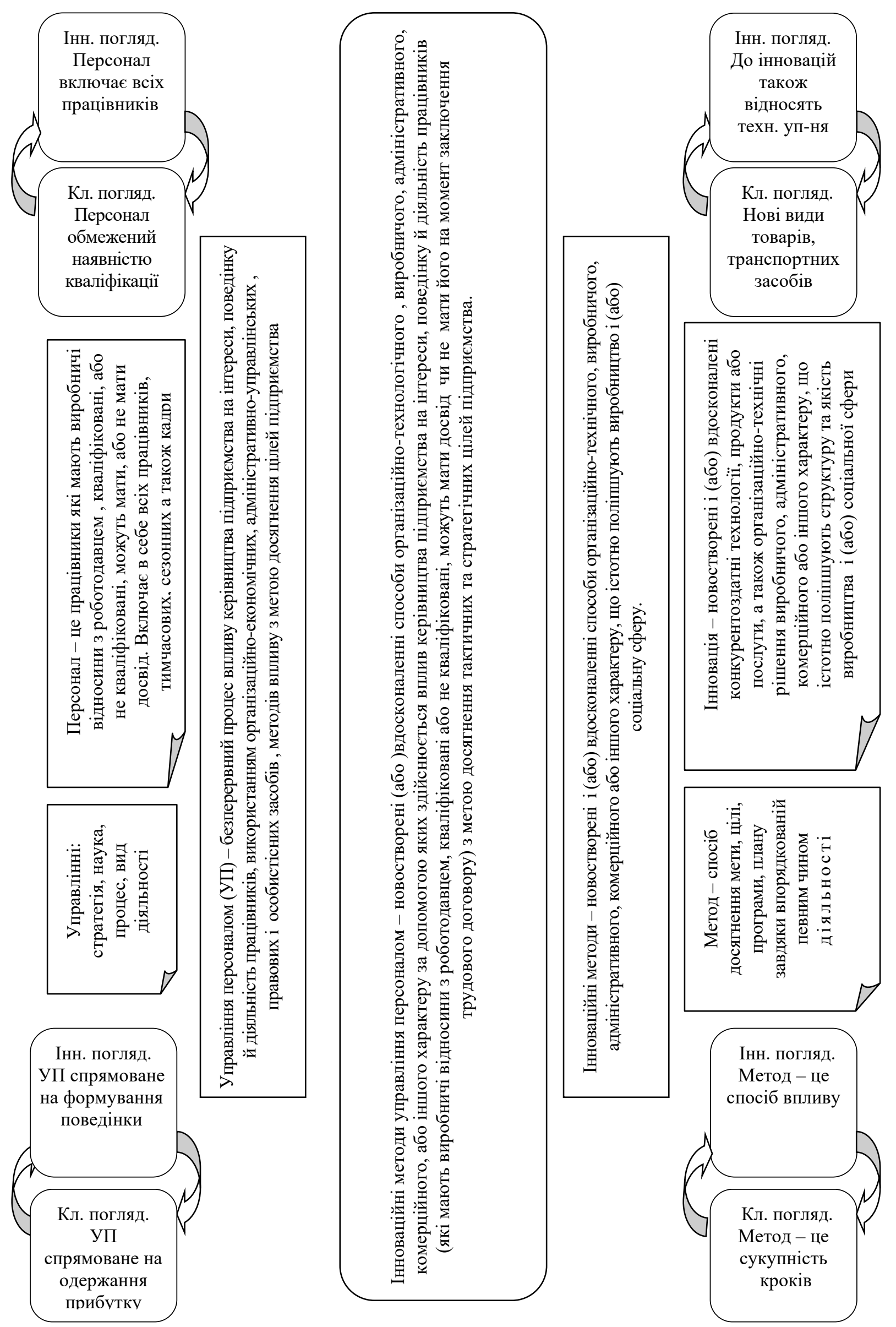


Рис.1 Праксеологічний контур понять «персонал», «управління», «інновації», «метод» та «інновачійні методи управління персоналом»

В рамках теми дослідження, при застосуванні праксеологічного підходу доцільно буде використовувати класифікацію інновацій за ступенем новизни, але виділити наступні види інновацій: радикально нові, покращуючі (ті, що удосконалюють вже існуюче) та псевдоінновації.

Як вже зазначалось, класичні методи управління персоналом поділяються на адміністративні, економічні та соціально-психологічні.

А.О. Касич та О.А. Бурба виділять наступні інноваційні методи: методи підбору персоналу, методи оцінки діяльності, управління кар'єрою, методи системи винагороди, методи навчання [5].

На думку автора, з огляду на праксеологічний підхід, доцільно внести в дану класифікацію ще одну складову «методи формування ефективної поведінки персоналу» (табл. 2).

Таблиия 2

Класифікація інноваційних методів управління персоналом

\begin{tabular}{|c|c|}
\hline $\begin{array}{c}\text { Класифікація інноваційних } \\
\text { методів управління персоналом }\end{array}$ & Інноваційні методи \\
\hline Підбор персоналу & $\begin{array}{l}\text { Аутсорсинг, аутстафінг, лізінг персоналу, хедхантинг, рекрутинг, } \\
\text { скрининг. }\end{array}$ \\
\hline Оцінка діяльності & $\begin{array}{l}\text { Автоматизація інформаційної системи управління персоналом, } \\
\text { системи таємного контролю працівника. }\end{array}$ \\
\hline Управління кар’єрою & Реінженерінг, розробка та застосування кар’єраграм тощо. \\
\hline Система винагород & $\begin{array}{l}\text { Внутрішній маркетинг, застосування преміального фонду, що } \\
\text { стимулює такі якості персоналу, як креативність та } \\
\text { інноваційність. }\end{array}$ \\
\hline Навчання & Тренінги, коучинг, самонавчання, E-learning, кейс стаді. \\
\hline $\begin{array}{l}\text { Методи формування ефективної } \\
\text { поведінки персоналу }\end{array}$ & $\begin{array}{l}\text { Альтер-его, сесія питань, символ, виклик, метод SCAMPER, } \\
\text { метод провокацій, рефреймінг, метод інверсії та інші. }\end{array}$ \\
\hline
\end{tabular}

Введена автором в класифікацію група методів дозволить здійснювати безперервний процес (планування, наймання, оцінювання, розвиток та мотивація) впливу керівництва підприємства на інтереси, поведінку й діяльність працівників (які мають виробничі відносини 3 роботодавцем, кваліфіковані або некваліфіковані, можуть мати досвід чи не мати його на момент заключення трудового договору), з використанням новостворених і (або) вдосконалених способів впливу з метою досягнення тактичних та стратегічних цілей підприємства.

Останнім часом інноваційні методи управління персоналом об'єднують в персонал-технології [6].

- персонал-технології позикової праці;

- навчальні персонал-технології;

- персонал-технології підбору та найму персоналу;

- персонал-технології підвищення ефективності роботи персоналу;

- персонал-технології контролю праці персоналу;

- інформаційні персонал-технології.

Технологія - сукупність методів (способів) виготовлення, видобутку, обробки або переробки та інших процесів, робіт і операцій, що змінюють стан сировини, матеріалів, напівфабрикатів чи виробів у процесі отримання продукції із заданими показниками якості.

Автор повністю погоджується з Лизуновою О. М., Іщенко Я. Г., Кондрашовою Г. В., що окремі методи управління персоналу (якими б інноваційними вони не були) не зможуть радикально змінити поведінку працівника, підвищити ефективність його діяльності. Як вже зазначалось «людина» багатогранний суб’єкт дослідження, саме тому автор для впливу на його поведінку необхідно використовувати сукупність методів - персонал-технології. 
Удосконалена автором класифікація інноваційних методів управління персоналом також може стати основою для класифікації персонал-технологій (табл. 3).

Таблиия 3

Класифікація персонал-технологій

\begin{tabular}{|c|c|c|}
\hline Персонал-технології & $\begin{array}{c}\text { Класифікація } \\
\text { інноваційних методів } \\
\text { управління персоналом }\end{array}$ & Інноваційні методи \\
\hline $\begin{array}{l}\text { Персонал-технологія залучення } \\
\text { персоналу }\end{array}$ & Підбор персоналу & $\begin{array}{l}\text { Аутсорсинг, аутстафінг, лізінг } \\
\text { персоналу, хедхантинг, рекрутинг, } \\
\text { скрининг. }\end{array}$ \\
\hline $\begin{array}{l}\text { Персонал-технологія оцінки } \\
\text { діяльності }\end{array}$ & Оцінка ді & $\begin{array}{lrr}\text { Автоматизація } & \text { інформаційної } \\
\text { системи } & \text { управління } & \text { персоналом, } \\
\text { системи } & \text { таємного } & \text { контролю } \\
\text { працівника. } & & \\
\end{array}$ \\
\hline $\begin{array}{l}\text { Персонал-технологія якісного } \\
\text { розвитку }\end{array}$ & $\begin{array}{l}\text { Управління кар’єрою, } \\
\text { навчання }\end{array}$ & $\begin{array}{l}\text { Реінженерінг, розробка та } \\
\text { застосування кар'єраграм, тренінги, } \\
\text { коучинг, самонавчання, E-learning, } \\
\text { кейс стаді }\end{array}$ \\
\hline $\begin{array}{l}\text { Персонал-технологія } \\
\text { стимулювання }\end{array}$ & Система винагород & $\begin{array}{l}\text { Внутрішній } \\
\text { застосування петреміального фонду, } \\
\text { що стимулює такі якості персоналу, } \\
\text { як креативність та інноваційність. }\end{array}$ \\
\hline $\begin{array}{l}\text { Персонал-технологія формування } \\
\text { ефективної поведінки }\end{array}$ & $\begin{array}{l}\text { Методи формування } \\
\text { ефективної поведінки } \\
\text { персоналу }\end{array}$ & $\begin{array}{l}\text { Альтер-его, сесія питань, символ, } \\
\text { виклик, метод SCAMPER, метод } \\
\text { провокацій, рефреймінг, метод } \\
\text { інверсії та інші. }\end{array}$ \\
\hline
\end{tabular}

Класифікація персонал-технологій, що представлена в таблиці $3 є$ узагальненою. Зрозуміло, що кожне підприємство при побудуванні системи управління персоналом буде використовувати ті персонал-технології, які $\epsilon$ ефективними саме для характеру його діяльності, враховують специфіку виробничого процесу та спрямовані на формування певної (вигідної як для підприємства так і для працівника) поведінки персоналу.

Висновки: Введена автором в класифікацію група методів, що дозволить здійснювати безперервний процес (планування, наймання, оцінювання, розвиток та мотивація) впливу керівництва підприємства на інтереси, поведінку й діяльність працівників (які мають виробничі відносини з роботодавцем, кваліфіковані або некваліфіковані, можуть мати досвід чи не мати його на момент заключення трудового договору), з використанням новостворених і (або) вдосконалених способів впливу з метою досягнення тактичних та стратегічних цілей підприємства. Сформоване комплексне поняття управління персоналом. Розроблена схема праксеологічного контуру понять «персонал», «управління», «інновації», «метод» та «інноваційні методи управління персоналом».

Подальші дослідження в управлінні персоналом, а саме в методах управління повинні бути сформовані з урахуванням трансформації у відносинах роботодавець-працівник та націлені на глобальні перетворення в економіці.

\section{Джерела та література}

1. Котарбинский Т. Трактат о хорошей работе / пер. с пол. Л. В. Васильева, В.И. Соколовского. Москва, $1975.270 \mathrm{c}$.

2. Макарейко Н. В.. Адміністративне право. Конспект лекцій, 5-е изд., перераб. и доп. - Москва: Высшее образование, 2009. 189 с.

3. Погорєлова Т.О., Ігнатьєва Ю.І. Система управління персоналом як основний елемент системи управління підприємством. Вісник Національного технічного університету «Харківській політехнічний інститут». Харків, 2013. № 21(994). С.127-134. 
4. Балабанова Л.В., Сардак О.В. Управління персоналом: підручник - Київ: Центр учбової літератури, 2011. 468 c.

5. Касич А. О., Бурба О. А. Інноваційні підходи в практиці управління персоналом конкурентоспроможного підприємства .Науковий вісник Ужгородського національного університету. Серія : Міжнародні економічні відносини та світове господарство. Ужгород, 2017. Вип. 16 (1). С. 130-134.

6. Лизунова О.М., Іщенко Я.Г, Кондрашова Г.В. Використання інноваційних методів управління персоналом підприємства. Електронне фахове видання Мукачівського національного університету: Економіка та суспільство. Мукачево, 2018 р. №14 С. 448-456.

7. Данильян О. Г., Тараненко В. М. Філософія: підручник 2-ге вид., допов. і переробл. - Харків: Право, 2012. $312 \mathrm{c}$.

8. Про інноваційну діяльність: Закон України від 04.07 .2002 р. №40 - IV. URL: http://sfs.gov.ua/arhiv/podatkova-baza-do-nabrannya-chinnosti-podatkovim-kodeksom/normativno-pravovabaza/zakoni-ukraini/arhiv-zakoniv-ukraini/zakoni-ukraini-za-2002-rik/print-59956.html (дата звернення 19.11.2019).

9. Руководство Осло. Рекомендации по сбору и аналізу данных по инновациям. - 3-е изд., совместная публикация ОЭСР и Евростата / пер. на рус. яз. - Москва: ГУ «Центр исследований и статистики науки», 2010. $107 \mathrm{c}$.

10. Тимочко Н. О. Економічна історія України: навч. посіб. - Київ: КНЕУ, 2005. 204 с.

\section{Referennces}

1. Kotarbinskii T. (1975) Traktat o khoroshei robote [A treatise on good work]. (L.V. Vasilieva, V.I. Sokolovskii). Moskow [in Russian].

2. Makarenko N.V. Administrativne pravo [Administrative Law]. Moskow: Vysshee obrazovanie [in Russian].

3. Pohorelova T.O. \& Ihnatieva Yu.I. (2013). Systema upravlinniia personalom yak osnovni element systemy upravlinniia pidpryemstvom [Personnel management system as a basic element of enterprise management system]. Visnyk Nacionslnoho technichnoho universitety "Kharkivskii politekhnichnii instytut» - Bulletin of the National Technical University «Kharkiv Polytechnic Institute», 21, 127-134 [in Ukrainian].

4. Balabanova L.V. \& Sardak O.V. (2011). Upravlinnia personalom [Personnel management]. Kyiv: Centr uchbovoi literatury [in Ukrainian].

5. Kasych A.O., Burba O.A. (2017). Innovaciini pidhody v praktyci upravlinnia personalom konkurentospromozhnoho pidpryemstva [Innovative approaches in the practice of personnel management of a competitive enterprise]. Naukovyi visnyk Uzhhorodskoho nacionalnoho ипiversitetu - Науковий вісник Ужгородського начіонального університету, 16, 130-134 [in Ukrainian].

6. Lyzunova O.M., Ischrnko Ya. H. \& Kondrashova H.V. (2018). Vykorystannia innovaciinykh metodiv upravlinnia personalom pidpryemstva [Use of innovative methods of enterprise personnel management]. Elektronne fakhove vydannya Mukachivs'koho natsional'noho universytetu: Ekonomika ta suspil'stvo - Electronic Professional Edition of Mukachevo National University: Economics and Society, 14, 448-456 [in Ukrainian].

7. Danulian O.H. \& Taranenko V.M. (2012) Filosofia [Philosophy]. Kharkiv: Pravo [in Ukrainian].

8. Zakon Ukrainy «Pro innovaciinu diyalnist» [The Law of Ukraine on Innovative Duty]. (n.d.). sfs.gov.ua. Retrieved from http: http://sfs.gov.ua/arhiv/podatkova-baza-do-nabrannya-chinnosti-podatkovimkodeksom/normativno-pravova-baza/zakoni-ukraini/arhiv-zakoniv-ukraini/zakoni-ukraini-za-2002-rik/print59956.html [in Ukrainian].

9. Rukovodstvo Oslo. Rekomendacii po sboru I analizu dannykh po innovaciiam (2010). Moskow: HU «Centr issledovaniia I statistiki nauki ». [in Russian].

10. Tymochko N.O. (2005) Ekonomichna istoriia Ukrainy [Economic History of Ukraine]. Kyiv: Kyivskii nacionalnii economachnii universitet [in Ukrainian]. 